Thursday, May 26.--Section of science. Secretaries were appointed as follows:-German, Dr. A. Riecke; French, M. A. de Lapparent; English, Dr. A. D. Waller.

Prof. Waldeyer presented, on behalf of the commission for investigating the anatomy of the brain, the report of the sitting of the committee of May 24 .

Prof. Waldeyer moved the following resolution :-

"The several academies and societies represented in the association are recommended to bring before their respective Governments, or other appropriate authorities, in the name of the association, a proposal to establish a special institution or department of institutions for the investigation of the central nervous system, where such organisations are not already in existence, or cannot be created otherwise." The resolution was carried.

The following resolution, giving the committee power of cooption, was also carried:-

"That the Brain Commission have the power of cooption, as recommended in the report just received."

Prof. von Bezold moved "That a committee be appointed to consider the best means of bringing existing organisations into accord with the views of the International Association of Academies." This resolution was carried.

Sir A. Geikie, on behalf of the International Geological Congress, moved the following resolution:- "The International Association having received and considered a reference made to it by the International Geological Congress held at Vienna, 1903, resolves to ask the International Geodetic Association to take into consideration whether, and (or) in what way, it can undertake or promote international cooperation in the investigation of the following subjects :-

"Precise determination of levels in mountain chains subject to earthquakes, with the view of ascertaining whether such chains are stable or are undergoing movements of elevation or depression.

"Measurements of the value of gravity, with the object, so far as geological questions are concerned, of throwing light on the internal distribution of masses in the earth and on the rigidity or isostasy of the terrestrial crust.' The motion was carried unanimously.

Prof. Credner proposed that the committee on sejsmological investigations, appointed on the proposition of Prof von Bezold, consist of the following members:-Prof. Schuster (chairman), Prof. Helmert, Prof. de Lapparent, Prof. Mojsisovics, Prof. Agamennone, Prof. A. P. Karpinski, Prof. W. C. Mendenhall. That the committee have power to coopt further members without votes. If a vacancy arise among the members of the committee, it shall have the power to fill up such vacancy subject to confirmation by the International Association.

Prof. Riecke moved the following resolution of the Academies of Göttingen, Leipzig, Munich, and Vienna :-

"That the International Association be requested to place the investigation of atmospheric electrical phenomena upon the list of its undertakings, and to arrange for carrying out observations upon atmospheric electricity for the period of two years at a large number of stations suitably distributed over the surface of the earth."

Prof. Schuster considered the matter to be in an experimental stage and hardly ready to be taken up by the association otherwise than as an experimental undertaking suitable for consideration by a committee, and proposed the following resolution, which was accepted by Prof. Riecke :-

"That a committee be nominated to prepare a plan for cooperation in investigations of atmospheric electricity, and to organise, if possible, such international cooperation for a period of two years."

Prof. von Bezold introduced the propositions of the Berlin Academy of Sciences relating to terrestrial magnetism, and moved "That the association nominate a special committee to consider as to the best methods of making accurate magnetic observations at sea with a view to carrying out a magnetic survey around a parallel of latitude." The motion was carried unanimously.

Sir David Gill presented the report of the Royal Society upon the undertaking for the measurement of the African arc of the 3oth meridian, and moved "That the report of the Royal Society be adopted, with the following amendments, viz. :-

NO. 1806 , VOL. 70]
"That after the concluding words there be added :-

"(I) That the association notes with much satisfaction the sympathetic communication of the Imperial Academy of Sciences, St. Petersburg, on the subject of the arc of meridian, and recommends that diplomatic action be taken with a view to the extension of Struve's arc to Egypt.

"(2) The association expresses the hope that steps will be taken by the German Government under the advice of the Berlin Academy of Sciences to extend the arc along Lake Tanganyika, either by triangles extending across the lake or along its eastern coast as may be found the more desirable." The report was adopted with the additions proposed.

Prof. Fredericq presented the report of the late Prof. Marey on the work of the Institut Marey, and moved the following resolution :-

"The International Association of Academies approves the nomination of MM. Lippmann, Amagat, Charles Richet, Blix, Einthoven, Grützner, Langendorff, Schenck, Athanasiu as new members of the "Association Internationale de l'Institut Marey.',

"After having considered the report of the late Prof. Marey, dated May 5, 1904, on the work of the institute, the association congratulates the committee of the Marey Institute in having obtained in France recognition as being of public utility, and thus secured the permanence of this international scientific organisation. The association expresses its best wishes for the success of the scientific work undertaken at the institute." The resolution was adopted unanimously.

Other standing committees were appointed as follows:For the investigation of terrestrial magnetism, Prof. von Bezold (chairman), Prof. Mascart, Prof. Palazzo, Sir Arthur Rücker, Lord Kelvin, Dr. Bauer, Prof. Liznar, General Rykacev, Prof. Wieckert, Dr. Paulsen.

For the investigation of atmospheric electricity, Prof Exner (chairman), Prof. Arrhenius, Prof. Mascart, Prof. Schuster, Prof. Righi, Prof. Ebert, Prof. Riecke.

For both these committees resolutions were passed giving powers of cooption and for filling vacancies, similar to that passed in the case of the committee on seismology.

\section{PROF. ADOLFO CANCANI}

$A$ MONG the various sciences, the one which during the last few years has lost the greatest proportion of its workers is probably seismology. Von RebeurPaschwitz, M. S. di Rossi, Ehlert, Pacher, and Contarini have followed each other in quick succession, and to this death roll, with feelings of sorrow, we are called upon to add the name of the distinguished investigator Adolfo Cancani. Although connected with the University of Modena, Prof. Cancani's work was chiefly carricd out while working with di Rossi at the observatory of Rocca di Papa, and later whilst engaged as an assistant at the Central Meteorological Observatory in Rome. At the former institution he introduced into seismometry the use of large and heavy horizontal pendulums the movements of which were recorded mechanically.

The first of these, which are probably the largest in the world, were 17 feet in height. The booms, made of $T$ iron, were Io feet in length, which at their outer ends carried in one case a block of marble and in the other a piece of pig iron. Beyond these heavy masses glass fibres recorded movements on a surface rotating at the rate of $60 \mathrm{~cm}$. per hour. With this apparatus, all of which was home made, and cost but a few pounds sterling, Cancani obtained some striking seismograms.

In addition to taking this new step in seismometry, Cancani devised a photo-chronograph, various seismoscopes, and other instruments.

Although his investigations extended to several departments of earth physics, his chief works are those relating to seismology.

In July, I903, at the Seismological Conference in 
Strassburg, at which with his chief, Dr. Luigi Palazzo, he acted as a delegate for Italy, he brought forward a scale for seismic intensities which he followed by a paper on the possible relationship between small changes in latitude and the occurrence of large earthquakes. His last published paper relates to the advantages to be obtained from continuously moving high speed record receiving surfaces.

Seismologists throughout the world know Cancani's work, but those who were privileged to know him personally have stored up remembrances of an enthusiastic worker, gentle and persuasive in his speech, and with a kindliness of disposition of rare occurrence. He leaves behind a gap difficult to fill, a loss to a family, to a department, and to a new science.

\section{NOTES}

Prof. Grorge Darwin, F.R.S., has been elected president of the British Association for the meeting to be held in South Africa next year.

AT the monthly meeting of the Royal Institution on Monday, the thanks of the members were returned to Dr. Andrew Carnegie for his donation of $1200 l$. to enable Prof. Dewar and Mr. R. A. Hadfield to prosecute their joint investigation on the physical properties of steel and other alloys at low temperatures; and to Dr. Frank McClean for his donation of Iool. to the research fund of the institution.

Prof. C. S, Sherrington, F.R.S., has been elected a member of the Imperial Academy of Medicine, Vienna.

IT is reported that the University of Göttingen has awarded its Otto Wahlbruch prize, of the value of $600 l$., to Prof. Wilhelm Pfeffer, professor of botany at Leipzig. The prize is awarded for the most important contribution to science during the past two years.

At the annual meeting of the Association of German Chemists, held at Mannheim on May 25, the Liebig gold medal for distinguished services in applied chemistry was presented to Dr. Rudolf Knietsch, of the Badische Anilinund Soda-Fabrik, the discoverer of the so-called contact process of sulphuric acid manufacture.

$\mathrm{ON}_{\mathrm{N}}$ the recommendation of the Rumford committee, the American Academy of Arts and Sciences has awarded the Rumford medal to Prof. E. F. Nichols, of Columbia University, for his researches on radiation, particularly on the pressure due to radiation, the heat of the stars, and the infra-red spectrum.

Science announces the death of Mr. Frederick A. Walpole, botanical artist of the U.S. Department of Agriculture. He was considered the best plant artist in the United States, his drawings having been used to illustrate various reports published by the Department of Agriculture and the Smithsonian Institution, as well as the narrative of the Harriman Alaska Expedition.

A REUTER telegram from Frankfort-on-Main says that at the forty-fifth general meeting of the German Engineers' Association the Grashof medal, instituted in honour of the founder of the association, was unanimously conferred on the two pioneers of steam turbine propulsion, the Hon. C. A. Parsons, of Newcastle-on-Tyne, and M. de Laval, of Stockholm.

THROUGH the efforts of an organisation known as the Edison Medal Association, a fund has been created to establish a medal to be known as the "Edison Medal," No. I 806 , VOL. 70] and the responsibility of annually awarding it has been entrusted to the American Institute of Electrical Engineers. A medal will be awarded this year by a committee soon to be selected from among the members of the institute.

Reuter's Agency learns that the expedition which left England in February under Lieut. Boyd Alexander for the forest region between the west coast and Lake Chad arrived in canoes at Ibi, 250 miles up the Binue River, in April. The explorers had already made some collections on the Binue, and intended landing at Ibi with the view of pushing north into Bauchi.

AN official communication issued at Simla on May 17 , and published in the Pioneer Mail of May 20, contains the following remarks :- "It has recently been stated in certain newspapers that the Government of India have rejected the offer made by Mr. Tata of a donation for aiding the foundation of an Institute of Science. This assertion is absolutely without foundation. So far from having rejected Mr. Tata's offer, the Government of India have promised a large subsidy to the scheme, and they have throughout the negotiations done everything within their power to facilitate its progress and aid the realisation of a project which has their fullest sympathy."

Dr. Friedrich Siemens, who died in Dresden a few days ago, was born in 1826 at Menzendorf, near Lübeck, and received his education in that town. In 1848 , says the Electrician, he came to England to introduce his brother's, Dr. Werner Siemens, telegraphic apparatus. Afterwards he worked with his other brother, the late Sir William Siemens, and succeeded in applying the latter's regenerative principle to furnaces in combination with gaseous fuel, thereby making possible the production of open-hearth steel and the melting of glass by the continuous process in tanks. $\mathrm{He}$ also invented the regenerative gas burner and stove, and brought out numerous inventions connected with the glass industry.

A Reuter message from Queenstown states that $\mathrm{Mr}$. Marconi is among the passengers on board the outward bound Cunard Steamer Campania. The daily newspaper which the Cunard Company have arranged to publish on board their four largest boats will be produced under $\mathrm{Mr}$. Marconi's personal supervision. There will be a regular editor and printing staff on board each liner. The news received from shore will be supplied through Reuter's Agency. Mr. Marconi stated that he would have the Campania in communication with America on Monday through Cape Breton station, and would keep in communication with the Cornwall station until Wednesday night or Thursday morning.

Mr. J. Donovan, I Anstey Road, Denmark Hill, S.E., would be glad if psychologists or other investigators could send him information or references bearing upon the following points:-(x) A fairly representative list of animals, invertebrate and vertebrate, that make sounds in extreme pain or distress, although such sounds never serve to induce their fellows to help or relieve them, or even attempt to do so. (2) (a) Have any observations or experiments been made to show whether the sound or cry of pain or shock has any influence toward hindering or checking the oncoming of catalepsy or swoon in the animal producing the sound? (b) Are animals that do not possess means of sound production more subject to catalepsy from pain or shock than those which possess means of sound production?

Dr. Luigi Magri contributes to the Atti dei Lincei, xiii. (I), 9, some observations on the relation of the index of 